\title{
MODEL PENYELESAIAN SENGKETA WARIS DALAM MASYARAKAT ACEH
}

\author{
Sayuthi \\ Pascasarjana Universitas Islam Negeri Ar-Raniry Banda Aceh \\ Dedy Sumardi \\ Pascasarjana Universitas Islam Negeri Ar-Raniry Banda Aceh
}

\begin{abstract}
Abstrak
Artikel ini menganalisis model-model penerapan teori penyelesaian sengketa warisan dalam masyarakat Bireuen, Aceh. Penyelesaian sengketa warisan di Aceh tidak selamanya dilakukan melalui sistem litigasi, melainkan dapat juga dilakukan dengan jalur non litigasi. Kajian ini dibatasi pada praktek penerapan teori-teori alternative dispute resolution yang terjadi pada masyarakat Bireun, Aceh serta menguraikan kecenderungan masyarakat Bireuen memilih menyelesaikan sengketa warisan melalui sistem peradilan gampoeng (desa). Pengumpulan data lapangan dilakukan dengan teknik mengamati praktek penyelesaian sengketa di masyarakat, dan wawancara mendalam dengan aparatur desa dan para pihak yang besengketa. Hasil penelitian menunjukkan bahwa masyarakat Bireuen, Aceh cenderung menggunakan teori negosiasi, konsiliasi dan fasilitasi melalui sistem peradilan adat yaitu peradilan gampoeng dan peradilan mukim. Kedua sistem peradilan gampoeng lebih mengedepankan upaya damai dan menjamin privasi antar anggota keluarga. Prinsip inilah menjadi pertimbangan masyarakat Bireuen, Aceh memilih menyelesaikan sengketa warisan mengikuti sistem peradilan adat dibandingkan sistem peradilan resmi negara sebagai ciri khas dari sistem peradilan modern yang diterapkan oleh negara bangsa.
\end{abstract}

Kata Kunci: alternative dispute resolution, warisan, non litigasi, Aceh

\section{Abstract}

This article analyzes the models of the application of the theory of the inheritance dispute resolution in Bireuen community, Aceh. The inheritance dispute resolution in Aceh is not always done through the litigation system, but can also be done through non-litigation channels. This study is limited to the practice of the application of the alternative dispute resolution theories that took place in Bireuen community, Aceh, and describes the tendency of the Bireuen community to choose to resolve the inheritance disputes through the gampoeng justice system. The field data collection was carried out by observing the practice of dispute resolution in the community, and in-depth interviews with village officials and the disputing parties. The results show that the Bireuen community, Aceh tends to use the theory of negotiation, conciliation and facilitation through the customary justice system, namely the gampoeng court and the mukim court. Both of the gampoeng justice systems prioritize peaceful efforts and 
ensure privacy between family members. This principle is a consideration for the Bireuen community, Aceh chooses to resolve the inheritance disputes following the customary justice system compared to the official state justice system as a characteristic of the modern justice system implemented by the nation state.

Key word: alternative dispute resolution, inheritance, non litigasi, Aceh

\section{A. Pendahuluan}

Studi ini mengkaji model penyelesaian sengketa warisan dalam masyarakat Aceh di Kabupaten Bireuen, Provinsi Aceh. Model penyelesaian sengketa warisan dilakukan melalui non litigasi atau di luar jalur peradilan. ${ }^{1}$ Tradisi penyelesaian sengketa dalam masyarakat Aceh bukanlah hal yang baru, melainkan sudah terjadi secara turun temurun melalui lembaga adat yang ada di Aceh. Kewenangan lembaga adat menyelesaikan sengketa diatur dalam Qanun Nomor 9 Tahun 2008 tentang Pembinaan Kehidupan Adat dan Adat Istiadat, dan Keputusan Bersama (SKB) antara Gubernur Aceh dengan Kepolisian Daerah (Polda) Aceh dan Majelis Adat Nomor 189/677/2011 tanggal 20 Desember 2011 tentang Penyelenggaraan Peradilan Adat Gampoeng dan Mukim. Muculnya regulasi ini berdampak pada lahirnya lembaga Peradilan Gampoeng (Desa). Peradilan gampoeng dipimpin oleh geuchik (kepala desa) dengan anggotanya yang terdiri dari imum meunasah (iman desa), tuha peut, tuha lapan, ${ }^{2}$ serta tokoh adat dan tokoh masyarakat ataupun tokoh agama. ${ }^{3}$

Kajian ini difokuskan pada dua aspek yang akan diuraikan sesuai dengan data yang diperoleh. Pertama, alasan masyarakat Aceh di Kabupaten Bireuen menggunakan

1Secara umum penyelesaian sengketa dilakukan melalui dua cara, yaitu litigasi dan non litigasi. Penyelesaian sengketa melalui jalur legitasi dilaksanakan di lembaga peradilan negara. Sedangkan penyelesaian sengketa melalui non legitasi dialkukan di luar proses peradilan negara. Dalam teori modern dikenal dengan konsep Alternative Dispute Resolution (selanjutnya digunakan istilah ADR). Di Indonesia ADR sering disebut istilah Alternatif Penyelesaian Sengketa (APS). ADR menawarkan model-model penyelesaian sengketa seperti negosiasi, konsultasi, konsiliasi, mediasi, fasilitasi, adjudikasi, arbitrase, peacebuilding, peace keeping, dan lain-lain. Suyud Margono, ADR Alternative Dispute resolution: Arbitrase Proses Pelembagaan dan Aspek Hukum (Jakarta: Ghalia Indonesia, 2004).; Syahrizal Abbas, Mediasi Dalam Perspektif Hukum Syariah, Hukum Adat, dan Hukum Nasional (Banda Aceh: Raja Grafindo Persada, 2009).

${ }^{2}$ Tuha peut dan tuha lapan adalah lembaga adat yang secara struktural berada di bawah Kepala Desa (Geuchik). Lembaga ini terdiri dari empat dan delapan unsur berasal dari komunitas masyarakat desa. Mujiburrahman dkk, Eksistensi dan Peran Lembaga Adat dalam Masyarakat di Propinsi Nanggroe Aceh Darussalam (Banda Aceh: Laporan Penelitian, Satuan Kerja BRR-Rrevitalisasi dan Pengembagan Kebudayaan NAD, 2006), 27; Rusdi Sufi dkk, Aceh Tanah Rencong (Yogyakarta: Multi Sosulindo Press, 2008).

3Snouck Hurgronje, Aceh: Rakyat dan Adat Istiadatnya (I) (Jakarta: INIS, 1996); Moehammad Hoesin., Adat Atjeh (Banda Aceh: Dinas Pendidikan dan Kebudayaan Propinsi Daerah Istimewa Aceh, 1970) ; Syahrizal Abbas, "Diyat dalam Kehidupan Sosial Budaya Masyarakat Aceh," Media Syariah VI, no. 11 (2004).; Tim Peneliti IAIN Ar-Raniry dan Biro Keistimewaan Aceh Provinsi NAD, Kelembagaan Adat Provinsi Nanggroe Aceh Darussalam (Banda Aceh: Ar-Raniry Press, 2006). 
pola ADR dalam menyelesaikan sengketa waris. Kedua, model ADR apa saja yang paling sering digunakan masyarakat Aceh di Bireuen dalam menyelesaikan sengketa waris. Tema ini penting untuk dikaji kembali didasarkan pada argumen pokok, yaitu Aceh sebagai satu-satunya daerah otonomi khusus yang melaksanakan formalisasi syariat Islam di Indonesia. Status ini membuka peluang me-revitalisasi lembaga adat Aceh sebelum lahirnya Undang-Undang Nomor 1 Tahun 1951 sangat berperan dalam menyelesaikan sengketa masyarakat Aceh. Selain itu merujuk pada teori ADR dengan sejumlah modelnya memungkinkan dipraktekkan ADR di Kabupaten Bireuen, sehingga ditemukan model ADR berkarakteristik masayrakat Aceh di Kabupaten Bireuen.

Data yang diperoleh untuk memperkuat argumen di atas dilakukan dengan teknik, observasi, wawancara mendalam, serta kajian dokumentasi terkait tema yang diteliti. Lokasi penelitian adalah Kabupaten Bireuen, salah kabupaten pemekaran dari kabupaten Aceh Utara. Kasus yang diangkat adalah kasus sengketa warisan yang terdapat di di Kecamatan Kota Juang, dan Kecamatan Gandapura sebagai sampel penelitian.

\section{B. Alternative Dispute Resolution}

Di beberapa negara seperti di Australia, ADR dikenal dengan external dispute resolution termasuk proses dan teknik penyelesaian sengketa. ${ }^{4}$ Di Indonesia ADR sering diartikan dengan Alternatif Penyelesaian Sengketa (APS), yaitu pola penyelesaian sengketa di luar pengadilan atau non litigasi. Term ADR memiliki dua makna yaitu alternative to ligitation dan alternatif to adjudication. Alternative to ligitation menunjukkan seluruh mekanisme penyelesaian sengketa di luar peradilan termasuk di dalamnya arbitrase. Alternatif to adjudication adalah model penyelesaian sengketa dengan mekanisme konsensus atau kooperatif seperti negosiasi, mediasi dan konsiliasi. ${ }^{5}$ Umumnya dalam proses penyelesaian sengketa melibatkan pihak ketiga yang berposisi netral baik sebagai pembuat keputusan maupun sebagai media dalam menyelesaikan konflik. Seperti model penyelesaian melalui mediasi dengan mengikutsertakan pihak ketiga yang berfungsi sebagai mediator atau fasilitator. Selanjutnya negosiasi hanya melibatkan kedua belah pihak yang bertikai.

\footnotetext{
4Sri Mamudji, "Mediasi Sebagai Alternatif Penyelesaian Sengketa Di Luar Pengadilan," Jurnal Hukum \& Pembangunan 34, no. 3 (2017): 195-196, http://jhp.ui.ac.id/index.php/home/ article/view/1440/1360.

${ }^{5}$ Margono, ADR: Alternative Dispute Resolution dan Arbritase Proses Pelembagaan dan Aspek Hukum.
} 
Terdapat sujumlah model penyelesaian sengketa dalam konsep ADR. Modelmodel tersebut diperutukkan sesuai dengan jenis dan karakteristik sengketa, baik dari segi substansi sengketa dan segi keterlibatan pihak lain.

\section{Negosiasi}

Negosiasi merupakan bentuk ADR yang paling mendasar. Proses negosiasi dilakukan oleh para pihak melalui diskusi untuk mencari suatu kesepakatan bersama, tanpa melibatkan pihak ketiga yang netral. ${ }^{6}$ Proses negosiasi dibangun oleh para pihak dengan saling menawarkan kepentingan mereka masing-masing, baik kepentingan individu ataupun kelompok. ${ }^{7}$ Teknik seperti kompetitif, kooperatif, lunak, keras dan intersert based adalah strategi untuk mencapai kesepakatan adantara kedua belah pihak dalam mengosiakan kepentingan mereka. ${ }^{8}$ Sekalipun negosiasi hanya melibatkan pihak yang bersengketa, dalam keadaan tertentu juga perlu melibatkan pihak ketiga sebagai pengemban amanah atau penerima kuasa. ${ }^{9}$ Kedua model negosiasi bisa dilakukan langsung oleh para pihak yang bersengketa dan juga dapat diwakilkan kepada orang lain sebagai negosiator yang ditunjuk. ${ }^{10}$

\section{Konsultasi}

Konsultasi sebagaimana dijelaskan dalam kamus Black's Law Dictionery, sebuah tindakan konsultasi atau perundingan seperti pasien dengan dokter, client dengan pengacara. Gunawan Widjaya dan Ahmad Yani mendefinisikan konsultasi berdasarkan pemahaman mereka dari pengetian yang dijelaskan dalam Black's law Dictionery, yaitu suatu tindakan yang bersifat personal antara suatu pihak tertentu yang disebut "klien" dengan pihak lain "konsultan" untuk memberikan pendapatnya dalam memenuhi kebutuhan klien. ${ }^{11}$

Makna konsultasi seperti dikemukakan di atas menunjukkan bahwa konsultasi adalah diskusi yang dilakukan oleh seseorang dengan pihak lain memiliki pemahaman, kemampuan secara ilmiah terhadap persoalan yang menjadi objek perselisihan guna dicarikan solusi terhadap persoalan yang dimilikinya. Solusi yang

${ }^{6}$ Gunawan Wijaya, Alternatif Penyelesaian Sengketa (Jakarta: Raja Grafindo Persada, 2005).

${ }^{7}$ Muhammad Azwar, "Prospek Penerapan Online Dispute Resolution dalam Upaya Penyelesaian Sengketa Bisnis di Indonesia," Media Juris 2, no. 2 (2019): 179-196, https://ejournal.unair.ac.id/MI/article/view/13912.

Hukum.

8Margono, ADR: Alternative Dispute Resolution dan Arbritase Proses Pelembagaan dan Aspek

${ }^{9}$ Gatot Soemartono, Arbitrase dan Mediasi di Indonesia (Jakarta: Gramedia Pustaka Utama, 2006).

${ }^{10} \mathrm{Ibid}$.

11Wijaya, Alternatif Penyelesaian Sengketa, 94.; Gunawan Widjaya dan Ahmad Yani, Hukum Arbitrase (Jakarta: Raja Grafindo Persada, 2003) 
diberikan oleh konsultan sifatnya tidak mengikat, tergantung kepada klien sendiri dalam mengambil keputusan.

\section{Konsiliasi}

Secara bahasa, konsiliasi berarti perdamaian atau upaya penyelesaian sengketa dengan cara persahabatan. Biasanya penyelesaian sengketa dengan konsiliasi dilakukan setelah proses negosiasi tidak menemukan solusi, sehingga menyebabkan konsiliasi sering diartikan dengan mediasi. Konsiliasi mengacu pada proses penyelesaian sengketa secara konsensus antar pihak, adapun pihak netral dapat berperan secara aktif maupun tidak aktif. Pihak-pihak bersengketa harus menyatakan persetujuan atas usulan pihak ketiga dan menjadikannya sebagai kesepakatan penyelesaian sengketa. ${ }^{12}$

Berpijak pada pemahaman konsiliasi nampaknya konsiliasi merupakan induk dari metode penyelesaian sengketa melalui pola ADR, dimana mediasi, arbitrase dan adjudikasi bisa dikatakan bagian dari konsiliasi. Jika dicermati lebih lanjut, konsiliasi memiliki model tersendiri dibangikan dengan mediasi, fasilitasi dan aribtrasi. Akan tetapi sejauh yang penulis telusuri teori konsiliasi tidak menjelaskan secara panjang lebar tentang teknis pelaksanaannya sebagaimana yang terdapat dalam teori ADR lainnya.

Seperti diuraikan oleh W.E. Simkin, menurut penulis konsiliasi merupakan upaya yang dilakukan untuk menghambat atau membatalkan penyelesaian sengketa melalui jalur litigasi, sehingga konsiliasi bisa dikatakan bagian dari ADR yang membawahi empat teori lainnya, yaitu mediasi, fasilitasi, arbitrasi dan adjudikasi. Dengan kata lain, konsiliasi menjadi payung bagi empat model penyelesaian sengketa di luar pengadilan dengan melibatkan pihak ketiga dalam posisi netral. Sementara dua model yang telah penulis uraikan di atas bisa dikatakan bentuk penyelesaian sengketa yang tidak melibatkan pihak ketiga atau keterlibatan pihak ketiga, tetapi tidak berpengaruh kuat terhadap proses penyelesaian sengketa.

\section{Mediasi}

Mediasi adalah sebuah proses penyelesaian sengketa dengan melibatkan pihak ketiga yang bersifat netral (mediator). Keterlibatan pihak ketiga berdasarkan kesepakatan antara para pihak. Kedudukan mediator hanya sebagai pihak yang memfasilitasi dan merancang sebuah diskusi antara para pihak, dimana para pihak sendiri yang membuat keputusan. Sementara seorang mediator tidak memiliki

12Margono, ADR: Alternative Dispute Resolution dan Arbritase Proses Pelembagaan dan Aspek Hukum.; Bandingkan dengan Wijaya, Alternatif Penyelesaian Sengketa. 
wewenang untuk memberikan kesimpulan atau kepastian hukum, bahkan ia tidak memiliki wewenang untuk menawarkan sebuah resolusi, termasuk memaksakan suatu keputusan pada pihak. ${ }^{13}$ Keputusan yang diambil berdasarkan kesepatan sifatnya tidak mengikat jika penyelesaian ditempuh melalui model mediasi di luar lembaga peradilan negara. Berbeda halnya jika mediasi dilakukan sebagai upaya konsiliasi saat proses peradilan, maka keputusannya bersifat mengikat para pihak.

\section{Fasilitasi}

Fasilitasi merupakan keterampilan dalam proses penyelesaian sengketa, dimana fasilitator berusaha melakukan komunikasi dengan pihak yang bersengketa sebagai upaya membangun dialog untuk menjembatani perbedaan mereka. Di sini pertemuan dan dialog tercipta karena berbagai komunikasi, persiapan dan aktifitas sebelum, sesudah dan selama dialog, sehingga para pihak mempercayai proses yang ditawarkan oleh fasilitator, karena itu fasilitasi merupakan instrumen yang akan membantu proses dialog. ${ }^{14}$

Fasilitasi bertujuan menciptakan kesepahaman bersama antara para pihak yang bersengketa, yang pada akhirnya mendorong mereka untuk mencapai kesepakatan sekaligus menghilangkan atau mengakhiri persengketaan atau konflik. Fasilitator bisa berbentuk individu atau lembaga yang mengkonsentrasikan diri pada bidang menyelesaikan sengketa, ia harus mengetahui peran dan strategi yang harus diterapkan selama proses fasilitasi berlangsung. ${ }^{15}$

Perbedaan dari kelima teori ADR di atas terletak pada perlu tidaknya alat bukti untuk meyakinkan para pihak dan pihak ketiga dalam menyelesaikan sengketa. Teori mediasi dan fasilitasi tidak selalu membutuhkan bukti-bukti. Berbeda halnya dengan fasilitasi memerlukan pembuktian.

\section{Peran Lembaga Adat Aceh dalam Menyelesaikan Sengketa \\ 1. Geuchik}

Geuchik atau Kepala Desa, memiliki beragam penulisan dalam tradisi adat Aceh (keuchi' atau keuckik). Secara bahasa berasal dari kata chik yang berarti tua kemudian ditambah dengan kata geu diartikan dengan orang yang dituakan. ${ }^{16}$ Secara istilah, geuchik adalah sebuah jabatan politik tingkat gampoeng di mana geuchik adalah

\footnotetext{
${ }^{13}$ Takdir Rahmadi, Mediasi Penyelesaian Sengketa Melalui Pendekatan Mufakat (Jakarta: Raja Grafindo Persada, 2011).

${ }^{14}$ Abbas, Mediasi Dalam Perspektif Hukum Syariah, Hukum Adat, dan Hukum Nasional.

${ }^{15}$ Marc Galanter, "Justice in Many Rooms: Courts, Private Ordering and Indegenous Law," Journal of Legal Pluralism, no. 19 (1981).

${ }^{16}$ Abdul Kadir Manyambeang, Keuchik dan Keujruen Blang dalam Masyarakat Aceh (Banda Aceh: Pusat Penelitian Ilmu-ilmu Sosial, 1979).
} 
kepala pemerintahan di tingkat gampoeng yang memiliki tugas dan wewenang. Catatan sejarah menjelaskan, geuchik diangkat oleh ulee balang. Snouck Hurgronje mengatakan bahwa jabatan geuchik adalah sebuah jabatan dengan sistem monarkhi, sehingga tidak mengherankan geuchik dijabat oleh anak-anak. ${ }^{17}$ Namun setelah ulee balang tidak eksis lagi, maka pengangkatan seorang geuchik dilakukan dengan sistem pemilihan oleh masyarakat desa tempat berdomisili geuchik yang dipilih. Geuchik kadang-kadang diartikan juga dengan kepala desa atau setingkat dengan kepala desa, namun menurut Teuku Ibrahin Alfian, ia membedakan antara geuchik dengan kepala desa, karena di samping mempunyai otoritas dalam bidang pemerintahan geuchik juga berkewajiban memelihara adat istiadat, dengan posisi yang demikian Alfian menganalogikan geuchik dengan istilah "bapak atau ayah gampoeng". ${ }^{18}$

Geuchik berfungsi sebagai pemelihara adat dalam gampoeng, namun karena geuchik ditunjuk oleh ulee balang, maka tugas lainnya adalah sebagai penyalur perintah dari ulee balang. ${ }^{19}$ Di samping itu geuchik juga bertanggung jawab dalam memakmurkan gampoeng, memberikan keadilan dalam menyelesaikan sengketa yang timbul dalam masyarakat. ${ }^{20}$

\section{Imum Gampoeng (Imum Meunasah)}

Imum meunasah adalah imam atau pimpinan dalam shalat atau orang yang memahami masalah agama khususnya menyangkut fikih, dikenal dengan sebutan teungku. Orang yang menjabat Imum meunasah dalam sebuah desa biasanya dipilih oleh masyarakat desa dengan mempertimbangkan beberapa kriteria, seperti menguasai pengetahuan agama Islam, sosok bijaksana, cerdas dalam memutuskan perkara terutama masalah agama. ${ }^{21}$

Sebutan untuk imum digunakan istilah teungku imum, namun di sebagian daerah di Aceh seperti di Kabupaten Aceh Barat, Aceh Selatan gelar teungku imum diperuntukkan bagi imam mesjid, sementara di Kabupaten Pidie disebut teungku meunasah. ${ }^{22}$ Di samping sebagai pemimpin dan orang yang bertanggung jawab pelaksanaan shalat jama'ah di desa, teungku imum juga memiliki tugas lain seperti menyelesaikan sengketa masyarakat, menetapkan penerimaan zakat, baik zakat mal

${ }^{17}$ Snouck Hurgronje, Aceh Dimata Kolonialis, Jilid I. (Jakarta: Yayasan Soko Guru, 1985).

${ }^{18}$ Tim Peneliti IAIN Ar-Raniry dan Biro Keistimewaan Aceh Provinsi NAD, Kelembagaan Adat Provinsi Nanggroe Aceh Darussalam.

${ }^{19}$ Manyambeang, Keuchik dan Keujruen Blang dalam Masyarakat Aceh.

${ }^{20}$ Rusdi Sufi dkk, Aceh Tanah Rencong.

${ }^{21}$ Tim Peneliti IAIN Ar-Raniry dan Biro Keistimewaan Aceh Provinsi NAD, Kelembagaan Adat Provinsi Nanggroe Aceh Darussalam.

${ }^{22}$ Ridwan Azwad, Aceh Bumi Iskandar Muda (Banda Aceh: Pemerintah Provinsi Nanggroe Aceh Darussalam., 2008). 
maupun zakat fitrah serta menentukan amil zakat, melaksanakan penyambutan harihari besar agama, pelaksanaan kenduri yang dilaksanakan di desa, memimpin urusan tajhiz mayit, dan segala kegitan menyangkut ritual keagamaan. ${ }^{23}$

\section{Tuha Peut}

Tuha peut secara bahasa terdiri dari dua kata yaitu tuha dan peut, tuha berarti tua sedangkan peut berarti empat. Tuha peut adalah lembaga adat memuat empat perwakilan yang dianggap sudah tua dan mempunyai pengaruh atau kharisma dalam masyarakat. Keempat unsur ini, yaitu unsur pemerintah, unsur agama, unsur pimpinan adat dan unsur cerdik pandai. Jumlah mereka tidak ada ketentuan yang pasti, akan tetapi sangat tergantung kepada jumlah penduduk desa. Tuha peut berfungsi sebagai penasehat kepala desa (geuchik) dan imum meunasah dalam bidang pemerintahan, hukum adat, adat istiadat, kebiasaan dalam masyarakat dan menyelesaikan sengketa dalam masyarakat. ${ }^{24}$

\section{Tuha Lapan}

Tuha lapan juga terdiri dari dua kata yaitu tuha dan lapan. Tuha tua sedangkan lapan adalah delapan. Tuha lapan adalah lembaga adat yang anggotannya terdiri dari delapan unsur yaitu unsur pemerintah, unsur agama, unsur pimpinan adat, pemuka masyarakat, cerdik pandai, unsur pemuda, unsur perempuan dan unsur kelompok organisasi masyarakat. Tuha lapan berfungsi sebagai lembaga musyawarah bertujuan memberikan inspirasi menyeluruh dari seluruh komponen masyarakat. ${ }^{25}$ Tuha lapan memiliki fungsi sebagai lembaga musyawarah bertujuan untuk memberikan inspirasi yang menyeluruh dan tepat terhadap seluruh komponen masyarakat. ${ }^{26}$

\section{Imum Mukim}

Imum mukim (ada juga yang menyebutnya dengan kepala mukim) adalah lembaga adat dalam bidang pemerintahan yang membawahi beberapa desa. Pemimpin dalam sebuah kemukiman disebut imum mukim atau kepala mukim. Jika merujuk pada struktur pemerintahan desa sekarang, pemerintahan mukim berada di bawah kecamatan, akan tetapi dalam sistem kepemerintahan tidak terdapat hirarki

\footnotetext{
${ }^{23}$ Tim Peneliti IAIN Ar-Raniry dan Biro Keistimewaan Aceh Provinsi NAD, Kelembagaan Adat Provinsi Nanggroe Aceh Darussalam.

${ }^{24}$ Mujiburrahman dkk, Eksistensi dan Peran Lembaga Adat dalam Masyarakat di Propinsi Nanggroe Aceh Darussalam.; Rusdi Sufi dkk, Aceh Tanah Rencong.

25Peraturan Daerah Provinsi Aceh Nomor 7 Tahun 2000 tentang Penyelenggaraan Kehidupan Adat Pasal 1 ayat 11, n.d.

26Tim Peneliti IAIN Ar-Raniry dan Biro Keistimewaan Aceh Provinsi NAD, Kelembagaan Adat Provinsi Nanggroe Aceh Darussalam.
} 
kepemimpinan antara mukim dan camat, sehingga mukim bukan merupakan perpanjangan tangan dari camat. Seseorang yang mendapat jabatan sebagai imum mukim dipilih oleh masyarakat dalam sebuah wilayah kemukiman berdasarkan suara terbanyak, atau bisa juga dengan sistem kesepakatan perwakilan dari desa yang berada dalam sebuah kemukiman. Biasanya satu kemukiman sedikitnya terdiri dari delapan desa. ${ }^{27}$

Tugas imum Mukin hanya sebatas menjaga dan memelihara, melestarikan adat, memberikan sanksi adat bagi pelanggar adat, menyelesaikan sengketa dalam masyarakat baik antara penduduk dalam satu desa maupun antar penduduk yang berbeda, namun masih berada dalam wilayah kemukiman yang ia pimpin, termasuk sengketa tapal batas..$^{28}$

\section{Pranata Sosial Penyelesaian Sengketa Waris di Aceh}

Penyesaian sengketa dalam masyarakat Aceh merupakan tanggung jawab dan wewenang geuchik apabila persoalannya hanya terjadi di kalangan penduduk desa yang dipimpin. Proses penyelesaian sengketa diselesaikan oleh geuchik bertempat di balai atau di meunasah (surau). Di kalangan masyarakat Aceh dikenal sistem peradilan gampoeng (desa). Dalam sistem peradilan gampoeng, yang bertidak sebagai ketua majelis terdiri dari geuchik, teungku meunasah (imam desa) dan tuha peut, masingmasing mereka bertindak sebagai hakim secara ex-officio. ${ }^{29}$ Apabila dalam tempo 2 (dua) bulan sengketa tidak dapat diselesaikan, persoalan ini dilaksanakan ke rapat tingkat mukim dalam tempo satu bulan diharapkan sengketa masyarakat selesai di tingkat mukim. ${ }^{30}$

Proses preadilan di tingkat mukim, yang bertindak sebagai pimpinan sidang adalah imum mukim dan geuchik-geuchik dalam kemukiman tersebut, ulama-ulama

${ }^{27}$ A. Hasjmy, Kebudayaan Aceh dalam Sejarah (Jakarta: Beuna, 1983).

${ }^{28}$ Selain lembaga adat yang diuraikan di atas, masih terdapat beberapa lembaga adat lainnya berfungsi sebagai penyelesai sengketa seperti keujruen blang (lembaga adat yang bertugas menata kehidupan petani sawah serta adat yang berlaku dalam bidang persawahan), peutua seuneubok (lembaga adat yang mengurus dan menjalankan adat terhadap perihal pembukaan lahan baru), panglima uteuen (lembaga adat yang mengurus dan menjalankan serta memelihara adat di hutan), panglima laot (adalah lembaga adat yang mengelola kehidupan dan adat nelayan dan kehidupan di sekitarnya) haria peukan (adalah lembaga yang mengurus di daerah pasar dan syah banda (lembaga adat yang melestarikan dan mengatur kehidupan di pelabuhan laut).Tim Peneliti IAIN Ar-Raniry dan Biro Keistimewaan Aceh Provinsi NAD, Kelembagaan Adat Provinsi Nanggroe Aceh Darussalam.

${ }^{29}$ T. Djuned., "Penerapan Sistem dan Asas-asas Peradilan Hukum Adat dalam Penyelesaian Perkara," in Pedoman Adat Aceh: Peradilan dan Hukum Adat, ed. M. Isa Sulaiman dan H. T. Syamsuddin (Banda Aceh: LAKA, 2001).; M. Zainuddin, Tarich Atjeh dan Nusantara (Medan: Pustaka Iskandar Muda, 1961).

${ }^{30}$ Teuku Raja Itam, "Penyelesaian Sengketa dan Bebagai Kasus," in Pedoman Adat Aceh: Peradilan dan Hukum Adat, ed. M. Isa Sulaiman dan H. T. Syamsuddin (Banda Aceh: LAKA, 2001). 
serta beberapa orang tua guna membentuk peradilan. ${ }^{31}$ Apabila di tingkat mukim juga tidak dapat diselesaikan atau ada pihak yang tidak puas, proses penyelesaian sengketa dilakukan di tingkat nanggroe atau sago dengan pemimpinnya ulee balang atau panglima sagoe. Jika ulee balang atau panglima sagoe tidak dapat menyelesaikannya, maka kasus tersebut di sampaikan kepada sultan. Kemudian sultan memerintahkan Mahkamah Agung untuk menyelesaikannya. ${ }^{32}$

Sistem peradilan Aceh yang pernah eksis dalam tradisi masyarakat Aceh tempo dulu menunjukkan praktek peradilan cenderung bersifat litigasi. Secara hirarki proses penyelesaian sengketa diselesaikan terlebih dahulu di peradilan tingkat gampoeng hingga tingkat Makamah Agung. Model peradilan ini membuktikan bahwa sistem peradilan modern yang dianut oleh pemerintahan negara bangsa (nation state) merupakan hasil adopsi dari sistem peradilan yang berlaku dalam tradisi mayarakat nusantara, khususnya Aceh. Setelah kemerdekaan Republik Indonesia tanggal 17 Agustus 1945, semua sistem dan ketatanegaraan turut berubah sejalan dengan perubahan undang-undang peradilan di Indonesia. Kondisi ini berdampak pada semua aturan tentang tatanan kehidupan masyarakat Aceh. Namun demikian, sistem peradilan yang awalnya bersifat litigasi, bersamaan kemerdekaan Republik Indonesia, berubah menjadi sistem peradilan non litigasi (peradilan gampoeng) dan peradilan mukim. Sedangkan peradilan yang bersifat litigasi menjadi wewenang negara Republik Indonesia.

Hingga saat ini, peradilan gampoeng dan peradilan mukim masih berfungsi seperti biasa dan bahkan menjadi kuat setelah daerah Aceh diberi kewenangan menjalankan syariat Islam secara legal formal dan penguatan adat istiadat Aceh dalam Undang-Undang Otonomi Khusus sebagai cikal bakal lahirnya Undang-Undang nomor 11 Tahun 2005 tentang Pemerintahan Aceh. Dampaknya seluruh sistem adat istiadat Aceh, seperti sistem peradilan gampoeng dan peradilan mukim memperkuat pengakuan dari negara, ${ }^{33}$ bahkan menjadi alternatif penyelesaian sengketa bagi

${ }^{31}$ M. Zainuddin, Tarich Atjeh dan Nusantara.

${ }^{32} \mathrm{Ibid}$.

${ }^{33}$ Setiap sengketa yang muncul di Aceh pertama-tama diselesaikan di tingkat gampoeng, apabila di tingkat gampoeng tidak selesai, maka akan dilimpahkan ke tingkat mukim. Apabila sampai tingkat mukim kasus tidak dapat diselesaikan dalam tempo waktu 1 bulan, maka akan diajukan ke pengadilan. Namun setelah Aceh diberikan otonomi khusus dan pelaksanaan Syari'at Islam secara kaffah, maka masyarakat Aceh ingin mengembalikan semua adat istiadat yang dulu pernah ada di Aceh, termasuk sistem peradilan gampoeng dan peradilan mukim. Itam, "Penyelesaian Sengketa dan Bebagai Kasus," 
masyarakat Aceh. Banyak kasus-kasus perdata dan pidana diselesaikan melalui sistem peradilan adat, tanpa harus diselesaikan melalui peradilan negara. ${ }^{34}$

\section{E. Karakteristik ADR dalam Masyarakat Aceh di Kabupaten Bireuen}

Praktek penyelesaian sengketa yang digunakan masyarakat Aceh mengikuti teori-teori modern tentang penyelesaian sengketa yang terdapat dalam ADR, walaupun dalam prakteknya tidak digunakan istilah-istilah modern yang digunakan untuk menyelesaikan sengketa. Sesuai data lapangan, ditemukan beberapa praktek yang sejalan dengan teori modern tentang penyelesaian sengketa.

1. Negosiasi

Umumnya masyarakat di Kabupaten Bireuen memilih menyelesaikan sengketa waris melalui negosisi disebabkan masyarakat tidak ingin masalah keluarga diketahui secara umum. ${ }^{35}$ Di samping itu masyarakat juga masih menginginkan agar hubungan kekeluargaan masih tetap berada dalam keadaan damai tanpa adanya perpecahan. Sehingga selama persoalan yang terjadi di antara mereka masih dapat diselesaikan secara kekeluargaan, tanpa perlu melibatkan pihak lain. ${ }^{36}$

Jikapun mereka tidak mampu menyelesaikan masalah tentang warisan yang terjadi di antara mereka, sebagian masyarakat Bireuen masih mencoba menyelesaikan secara kekeluargaan dengan melibatkan anggota keluarga yang tidak termasuk ahli waris, namun memahami hukum Islam khususnya hukum waris. Tujuannya supaya masalah mereka dapat diselesaikan secara kekeluargaan dan tidak terjadi ketegangan yang lebih berat lagi dan untuk mejaga keutuhan hubungan kekeluargaan.

Praktek negosiasi digunakan masyarakat Bireun sebagai salah satu upaya menyelesaikan sengketa warisan didasarkan pada informasi dari informan, para pihak menyelesaikan sengketa secara kekeluargaan, atau musyawarah sesama anggota keluarga. ${ }^{37}$ Proses negosiasi ditempuh dengan cara salah satu pihak mendatangi pihak lain untuk mempertanyakan persoalan yang mereka hadapi agar dapat diselesaikan secara kekeluargaan. ${ }^{38}$ Ada juga negosiasi yang menjurus kepada negosiasi keras, dimana salah satu menekan pihak yang lain agar bersedia menerima keputusan yang

\footnotetext{
34Dedy Sumardi, Ratno Lukito, dan Moch Nur Ichwan, "Legal Pluralism within the Space of Sharia: Interlegality of Criminal Law Traditions in Aceh, Indonesia," Samarah 5, no. 1 (2021): 426-449, https://doi.org/10.22373/sjhk.v5i1.9303.

${ }^{35}$ Wawancara dengan salah satu pihak yang bersengketa di Desa Lapang Barat Kecamatan Gandapura, 26 Oktober 2009.

${ }^{36}$ Wawancara dengan salah satu pihak yang bersengketa di Desa Bireuen Meunasah Blang, Kecamatan Kota Juang, Bireuen Meunasah Blang, 8 Nopember 2009.

37Wawancara dengan Pak Amir Geuchik Desa Cot Pu'uk, Mursal (Tuha Lapan) Desa Cot Pu'uk, Desa Cot Pu'uk, 28 Oktober 2009.

${ }^{38}$ Wawancara dengan salah satu pihak yang bersengketa di Desa Lapang Barat Kecamatan Gandapura, 26 Oktober 2009.
} 
telah dibuat oleh salah satu pihak dengan alasan bahwa keputusan tersebut adalah yang benar. Praktek ini terjadi di Desa Cot Teube Kecamatan Gandapura. ${ }^{39}$ Berdasarkan keterangan informan, nampaknya upaya penyelesaian yang dilakukan secara kekeluargaan sejalan dengan teori negosiasi, diselesaikan antara para pihak tanpa melibatkan pihak ketiga.

Dari hasil wawancara dengan sejumlah responden baik para pihak, maupun dengan tokoh masyarakat dan pemangku adat di Kabupten Bireuen menyatakan bahwa setiap terjadi sengketa warisan, langkah pertama yang ditempuh masyarakat adalah melakukan komunikasi dua arah, tanpa melibatkan pihak ketiga untuk mencari kesepakatan. Namun dari sejumlah kasus yang penulis telusuri penyelesaian sengketa dengan cara ini jarang menemukan titik temu.

Akan tetapi ada juga beberapa kasus yang dapat diselesaikan dengan cara kekeluargaan. Seperti kasus yang terdapat di desa Lingka Kuta, Kemukiman Gandapura Timur, Kecamatan Gandapura. ${ }^{40}$ Setelah proses penyelesaian sengketa dapat diselesaikan, kemudian para pihak menghubungi kepala desa untuk membuat surat keputusan dan penetapan ahli waris serta membuat surat kepemilikan terhadap benda tidak bergerak. Surat keputusan ini biasa surat kepemilikan tanah dan bangunan, jika terdapat bangunan di atasnya. ${ }^{41}$

Ketika penyelesaian kasus seperti ini tidak dapat diselesaikan, umumnya masyarakat menyampaikan kepada pihak aparat desa melalui kepala desa atau sekretaris desa, disamping ada juga yang di sampaikan melalui imum meunasah. Pengajuan kasus tentang kewarisan kepada aparat desa apabila dalam keluarga mereka tidak ada tokoh yang memahami tentang hukum kewarisan.

Berbeda dengan kasus yang terjadi pada keluarga mereka, dimana mereka bukanlah termasuk ahli waris (kerabat jauh), namum kerabat tersebut adalah orang yang memahami tentang hukum Islam, khususnya masalah mawaris, maka kasus tersebut diajukan kepada tokoh tersebut. ${ }^{42}$ Untuk penyelesaian harta warisan dengan cara ini penulis tidak menemukan kasusnya. Walaupun demikian penulis meyakini hal ini sangat memungkinkan terjadi, sebab masalah harta warisan umumnya masyarakat

\footnotetext{
${ }^{39}$ Wawancara dengan Sofyan, warga masyarakat Desa Cot Teubee Kecamatan Gandapura, Cot Teubee 15 Oktober 2009.

${ }^{40}$ Wawancara dengan salah satu pihak yang bersengketa di Desa Lapang Barat Kecamatan Gandapura, 26 Oktober 2009.; Wawancara Bapak Bakhtiar, Tokoh Masyarakat Desa Lingka Kuta, Kecamatan Gandapura, 27 Desember 2009.

${ }^{41}$ Wawancara dengan salah satu pihak bersengketa di Desa Lingka Kuta, Lingka Kuta 27 Desember 2009, n.d.; Wawancara Bapak Bakhtiar, Tokoh Masyarakat Desa Lingka Kuta, Kecamatan Gandapura, 27 Desember 2009.; Wawancara dengan Tgk. Murtadha Mustafa Kepala Desa Lingka Kuta, Lingka Kuta 27 Desember 2009., n.d.

${ }^{42}$ Wawancara dengan Mursal (Tuha Lapan) Desa Cot Pu'uk, Desa Cot Pu'uk, 28 Oktober 2009.
} 
masih menghindari (merahasiakan) agar tidak diketahui oleh pihak lain atau masyarakat umum. Mengingat perkara harta warisan adalah masalah keluarga, maka masyarakat mencoba menyelesaikan secara kekeluargaan selama masih memungkinkan diselesaikan di kalangan keluarga sendiri.

Untuk model penyelesaian sengketa yang melibatkan keluarga dekat yang memahami hukum Islam, selain ahli waris, ia juga termasuk tokoh dalam masyarakat. Model ini sepintas sejalan dengan model arbitrasi, akan tetapi hal ini juga belu sepenuhnya sejalan dengan prinsip arbitrasi, mengingat tokoh tersebut tidak memiliki kewenangan memberikan kekuatan hukum seperti di atur dalam undang-undang arbitrasi, sehingga model penyelesaian seperti ini kurang tepat dikatakan model arbitrasi.

Model ini juga bisa dikatakan model ADR melalui teori tahkim, namun demikian ada beberapa kalangan berpendapat bahwa tahkim bisa disepadankan dengan arbitrasi sebagaimana yang telah penulis uraikan di atas. Menurut penulis proses penyelesian sengketa dengan pola seperti ini sejalan dengan model tahkimwalaupun belum mendapat pengakuan yang tegas dalam sistem hukum ADR di Indonesia.

\section{Konsultasi}

Masyarakat Bireuen memilih menyelesaikan sengketa dengan cara konsultasi. Mereka berargumen masalah warisan sebagai masalah keluarga tidak ingin diketahui oleh masyarakat luas, serta untuk menghidari terjadinya pertentangan yang lebih luas. Konsultasi dilakukan untuk mecari langkah yang terbaik untuk ditempuh agar persoalan yang terjadi dapat diselesaikan dengan baik. ${ }^{43}$

Ada juga yang berpendapat bahwa alasan masyarakat Bireuen menyelesaikan perkara kewarisan secara negosiasi dan konsultasi untuk menghidari hak peurae. ${ }^{44}$ Namum dari sejumlah desa yang penulis teliti, aparat desa mengaku bahwa hak peurae tidak ditentukan jumlah yang harus dibayar, bahkan dari hasil observasi yang penulis lihat, aparat desa tidak meminta hak peurae. Namum mereka hanya meminta agar para ahli waris yang diselesaikan sengketa melalui peradilan gampoeng agar memberikan sedekah seikhlasnya untuk pembangunan mesjid. ${ }^{45}$

\footnotetext{
${ }^{43}$ Wawancara dengan salah satu pihak yang bersengketa di Desa Bireuen Meunasah Blang, Kecamatan Kota Juang, Bireuen Meunasah Blang, Tanggal 8 Nopember 2009.

${ }^{44}$ Hak Peurae adalah bagian yang harus diberikan kepada pihak lain yang membagikan harta warisan atau peradilan adat sebesar $5 \%$.

${ }^{45}$ Wawancara dengan Tgk. Zakaria Imum Meunasah Desa Cot Pu'uk, MursalTuha Lapan Desa Cot Pu'uk, n.d. dan Hasil Observasi pada tanggal 25 Desember 2009 di Desa Bireuen Meunasah Blang.
} 
Penyelesaian sengketa warisan yang tidak dapat diselesaikan melalui negosiasi, mereka memilih untuk diselesaikan melalui teori konsultasi. Seperti kasus yang terjadi di desa Meunasah Blang, Kemukiman Bireuen, Kecamatan Kota Juang. ${ }^{46}$ Dalam kasus ini salah satu kelompok dari salah satu pihak setelah gagal melakukan negosiasi dengan pihak lain, mereka mendatangi tokoh masyarakat untuk berkonsultasi tentang bagaimana sebaiknya persoalan itu diselesaikan. Kemudian konsultan memberikan masukan agar mereka segera melakukan pembagian harta warisan dengan jalan kekeluargaan atau di ajukan kepada aparat desa. Namun pihak yang mendatangi tokoh masyarakat (konsultan) tidak berhasil memperoleh keputusan, karena pihak yang satu lagi tidak bersedia diselesaikan dengan cara konsultasi. Kasus ini tidak diajukan kepada aparat desa dengan pertimbangan tidak ingin terjadi keributan mengenai harta warisan, sehingga diketahui oleh masyarakat umum. Penyelesaian kasus ini menjadi tertunda. Sebaliknya mereka hanya meminta kepada aparat desa apabila pihak yang satu lagi ingin menjual harta yang belum difaraidhkan agar aparat desa tidak membuat dan menandatangani surat jual beli terhadap tanah dan bangunan tersebut serta akta kepemilikan tanah dan bangunan. ${ }^{47}$

\section{Fasilitasi}

Penyelesaian sengketa melalui lembaga fasilitasi yang terdapat di Kabupaten Bireuen bukan berdasarkan atas keinginan para pihak yang bersengketa. Akan tetapi dilandasai pada kebijakan aparat desa. Dari hasil penelitian yang ditemukan di lapangan terdapat dua pendekatan yang berbeda. Pertama, fasilitasi digunakan setelah upaya penyelesaian sengketa melalui peradilan gampoeng tidak mendapatkan titik temu. Sesuai kebijakan aparat desa dan tokoh masyarakat memilih bentuk fasilitasi. Uniknya praktek fasilitasi dilakukan oleh tokoh masyarakat yang ditunjuk berdasarkan kesepakatan aparat dan tokoh masyarakat desa. Sementara yang menjadi fasilitator adalah dari kalangan masyarakat setempat, bisa dari aparat desa dan juga dari tokoh masyarakat. ${ }^{48}$ Fasilitasi model seperti ini terdapat di Kecamatan Gandapura.

Sedangkan penyelesaian sengketa melalui fasilitasi bentuk kedua ditempuh setelah adanya kasus yang diajukan kepada aparat desa, kemudian aparat desa menghubungi para pihak secara terpisah untuk mencari bukti dan pendekatan untuk

\footnotetext{
46Wawancara dengan Bapak Umar Hasan, Ketua MAA Kabupaten Bireuen, 30 September 2009. Beliau juga sebagai Imum Mukim kemukiman Bireuen Kecamatan Kota Jaung) Bireuen Meunasah Blang 30 September 2009; Wawancara dengan salah satu pihak yang bersengketa di Desa Bireuen Meunasah Blang, Bireuen Meunasah Blang, Tanggal 11 Nopember 2009.

${ }^{47}$ Wawancara dengan salah satu pihak yang bersengketa di Desa Bireuen Meunasah Blang, Kecamatan Kota Juang, Bireuen Meunasah Blang, 8 Nopember 2009.

${ }^{48}$ Wawancara dengan Bapak Amir Keuchik Desa Cot Pu'uk, Jafar, Ketua Tuha Peut, Mursal Tuha Lapan Desa Cot Pu'uk Kecamatan Gandapura, Cot Pu'uk, 28 Oktober 2009.
} 
mengadakan perdamaian. Setelah tercapai kata sepakat dari para pihak, kemudian kasus tersebut diselesaikan secara damai. ${ }^{49}$

Berdasarkan hasil wawancara dengan beberapa responden ditemukan bahwa penyelesaian sengketa dilakukan dengan cara pendekatan yang dilakukan oleh aparat desa terhadap individu, lalu dibuat suatu kesepakatan secara bersama-sama. Kesepatan ini biasanya dilakukan di Kantor Kepala Desa dihadiri oleh para pihak, geuchik, imum meunasah, dan tuha peut..$^{50}$ Menariknya komunikasi itu dilakukan setelah adanya pengaduan dan mengumpulkan bukti-bukti yang otentik. Jika memiliki buktibukti otentik, maka proses ini mengarah kepada teori adjudikasi. ${ }^{51}$

Sementara di Desa Cot Pu'uk proses penyelesaian sengketa dengan model fasilitasi dilakukan setelah melalui proses peradilan gampoeng dan tidak menemukan hasil kesepakatan. Pelaksanaan fasilitasi dilakukan berdasarkan kesepakatan aparat desa dan tokoh masyarakat. Tokoh masyarakat berfungsi sebagai fasilitator. Jumlah fsilitatornya terkadang lebih dari satu orang sesuai keputusan aparat desa dan tokoh masyarakat. ${ }^{52}$

Dua model fasilitasi yang dipraktekkan dalam masyarakat baik di Desa Cot Pu'uk Kecamatan Gandapura maupun di Desa Bireuen Meunasah Blang Kabupaten Bireuen, kelihatannya cenderung berbeda dari teori-teori yang terdapat dalam ADR. Hal ini merujuk pada data lapangan bahwa fasilitator dihubungi oleh para pihak dan atas kesadaran sendiri, bukan kebijakan/saran dari pihak lain. Model fasilitasi seperti ini terdapat di Desa Cot Pu'uk. Sebagai catatan bahwa fasilitasi model ini menurut aparat desa Cot $\mathrm{Pu}^{\prime} u k$ belum mereka praktekkan, melainkan tahapan penyelesaian sengketa yang akan ditempuh jika terdapat penolakan atau deadlock. Terlepas dari kenyataan tersebut, menurut Mursal (tuha lapan desa Cot Pu'uk), praktek fasilitasi sebagaimana kriteria yang terdapat dalam teori ADR walaupun ia tidak memenuhi kualifikasi sebagai fasilitator, tetapi pernah dipraktekkan oleh seorang warga desa Samuti, namun sayangnya tokoh tersebut telah meninggal dunia. Atas dasar praktek inilah tokoh masyarakat Cot Pu'uk membuat kebijakan tentang model fasilitasi.

\footnotetext{
${ }^{49}$ Observasi dan hasil wawancara dengan Muhammad Yani, Sekretaris Desa Bireuen Meunasah Blang Kecamatan Kota Juang, Bireuen Meunasah Blang, 29 Oktober 2009.

${ }^{50}$ Wawancara dengan Muhammad Yani, Sekretaris Desa Bireuen Meunasah Blang Kemukiman Bireuen Kecamatan Kota Juang, di Desa Bireuen Meunasah Blang 29 Oktober 2009; Wawancara dengan Pak Amir, Keuchik Desa Cot Pu'uk, Jafar, Ketua Tuha Peut, Mursal Tuha Lapan Desa Cot Pu'uk Kecamatan Gandapura, Cot Pu'uk, 28 Oktober 2009.

${ }^{51}$ Wawancara dengan Muhammad Yani, Sekretaris Desa Bireuen Meunasah Blang Kemukiman Bireuen Kecamatan Kota Juang, di Desa Bireuen Meunasah Blang 29 Oktober 2009.

${ }^{52}$ Wawancara dengan Pak Amir, Keuchik Desa Cot Pu'uk, Jafar, Ketua Tuha Peut, Mursal Tuha Lapan Desa Cot Pu'uk Kecamatan Gandapura, Cot Pu'uk, 28 Oktober 2009.
} 
Sementara model fasilitasi yang terdapat di Desa Bireuen Menunasah Blang, penyelesaian akhir tidak diselesaikan oleh fasilitator, tetapi penyelesaiannya dilaksanakan melalui peradilan gampoeng. Jadi konsep fasilitasi di desa ini bertujuan untuk mempelajari duduk perkara, mencari bukti-bukti otentik, melakukan komunikasi pemahaman dan ajakan agar persoalan mereka dapat diselesaikan secara damai. Setelah adanya kesamaan kehendak dan niat baik para pihak bersengketa untuk berdamai, maka disusun jadwal untuk penyelenggaraan peradilan gampoeng.

Proses fasilitasi yang dipraktekkan di desa Bireuen Meunasah Blang setelah menerima pengajuan perkara oleh Sekretaris Desa, sekretaris desa kemudian melakukan pendekatan secara individu kepada para pihak, ditemui secara langsung maupun secara tidak langsung menggunakan media elektronik. ${ }^{53}$

\section{Arbitrase atau Tahkim}

Model tahkim atau arbitrase juga ditemukan dalam penyelesaian sengketa di Kabupaten Bireuen. Sebagaimana hasil wawancara dengan beberapa tokoh, seperti imum Mukim Buket Rata Kecamatan Gandapura Bapak A. Rahman. Beliau mengatakan, kalau dalam upaya penyelesaian di tingkat gampoeng tidak berhasil, kadang-kadang kasus tersebut diajukan kepada Abon (sebutan lain untuk ulama pesantren). Hal senada juga terdapat di desa Cot Pu'uk Kemukiman Gandapura Timu Kecamatan Gandapura. ${ }^{54}$

Pola penyelesian sengketa sebagaimana yang diuraikan di atas, nampaknya tidak tepat dikatakan penyelesaian sengketa melalui arbitrase, karena keputusannya tidak mengikat. Hal ini disebabkan karena kalau ada pihak yang tidak menerima, maka dapat diselesaikan dengan cara lain atau dengan model lain.

\section{Suloh}

Suloh merupakan upaya akhir dari penyelesaian perkara yang dilakukan di peradilan gampoeng. Penyelesaian sengketa melalui peradilan gampoeng adalah penyelesaian sengketa dengan mengedepankan penyelesian secara damai bukan bersifat putusan perkara sebagaimana yang diselesaikan melalui proses ligitasi. Oleh karena itu setiap penyelesian perkara melalui peradilan gampoeng di tutup dengan suloh.

\footnotetext{
${ }^{53}$ Observasi terhadap Muhammad Yani, Sekretaris Desa Bireuen Meunasah Blang, Kecamatan Kota Juang, Bireuen Meunasah Blang 29 Oktober 2009.

${ }_{54}$ Wawancara dengan A. Rahman Imum Mukim Buket Rata, Kecamatan Gandapura, Cot Teubee, 26 Oktober 2009; Wawancara dengan Pak Amir, Keuchik Desa Cot Pu'uk, Jafar, Ketua Tuha Peut, Mursal Tuha Lapan Desa Cot Pu'uk Kecamatan Gandapura, Cot Pu'uk, 28 Oktober 2009.
} 
Suloh dalam penyelesaian perkara tentang waris berbeda dengan suloh terhadap penyelesaian sengketa lainnya, seperti perkelahian atau pembunuhan. Suloh dalam penyelesaian perkara dilaksanakan dengan upacara adat khusus, yaitu tepung tawar, disamping adanya pembayaran denda yang dibebankan kepada para pihak dan disertai dengan do'a bersama. Setelah selesai membaca do'a dilanjutkan dengan bersalaman dan saling mema'afkan. Akibat dari proses penyelesaian sengketa dengan cara tersebut awalnya pihak yang dulunya bermusuhan, berubah menjadi sebuah persaudaraan baru.

Sedangkan suloh yang dilaksanakan dalam menyelesaikan perkara kewarisan tidak dibarengi dengan upacara adat serta tepung tawar, melainkan sekedar salamsalaman dan pernyataan saling ma'af-mema'afkan. Alasannya adalah sengketa tentang persoalan harta warisan adalah persoalan keluarga yang sebelumnya tidak dapat diselesaikan secara kekeluargaan dan diselesaikan melalui lembaga peradilan adat. Di samping itu juga terhadap persoalan warisan jarang mengakibatkan pertumpahan darah.

\section{F. Sistem Peradilan Adat Aceh}

\section{Peradilan Gampoeng}

Berdasarkan hasil wawancara dengan Ketua Majelis Adat Aceh (MAA) Kabupaten Bireuen, Bapak Umar Husen, proses penyelesaian sengketa di tingkat gampoeng dilaksanakan melalui proses peradilan gampoeng. Prosedur yang dilakukan oleh para pihak bersengketa yaitu mendaftar ke kantor geuchik, selanjutnya pimpinan desa menjadwalkan waktu untuk melaksanakan proses peradilan gampoeng. Mereka yang ikut hadir dalam proses persidangan terdiri geuchik sebagai ketua sidang, anggotanya terdiri dari imum meunasah, tuha peut, tuha lapan, aparat desa, tokoh masyarakat, pemuka agama dan seorang notulensi. Menyangkut tentang tempat pelaksanaan Peradilan Adat Gampoeng adalah di Kantor Geuchik atau di meunasah dan terbuka untuk umum, khususnya untuk menggelar sidang dalam menyelesaikan sengketa waris tidak dilaksanakan di Kantor Keuchik atau di meunasah, namun digelar di tempat yang agak private seperti di rumah Keuchik atau rumah imum gampoeng serta ditutup untuk umum. Hal dilakukan dengan pertimbangan bahwa sengketa waris merupakan sengketa keluarga, maka demi menjaga marwahkeluarga yang bersengketa, maka sidang sengketa waris dilaksanakan ditempat yang memiliki privasi. ${ }^{55}$

${ }^{55}$ Wawancara dengan Bapak Mansur Saidi, Pengurus MAA Kabupaten Bireuen Bidang Adat, Bireuen 15 November 2009. 
Secara substansi, penyelesaian kasus masalah pembagian harta warisan merujuk pada hukum Islam. Jikapun ada para pihak meminta membagikan harta warisan tidak mengacu pada hukum Islam, umumnya tokoh masyarakat tidak bersedia, tetapi apabila dikemudian hari mereka membagikan tidak sesuai dengan hukum Islam, maka tindakan para pihak tersebut tidak menjadi tanggungjawab tokoh masyarakat, melainkan atas inisiatif para pihak bersengketa. Setelah selesai melakukan pembagian dengan pola sendiri, maka aparat desa akan membuat surat penetapan berisi hak masing-masing ahli waris dalam bentu surat dan keperluan administrasi lainnya. 56

Struktur dan Peran Penyelenggaraan Peradilan Adat Tingkat Gampoeng ${ }^{57}$

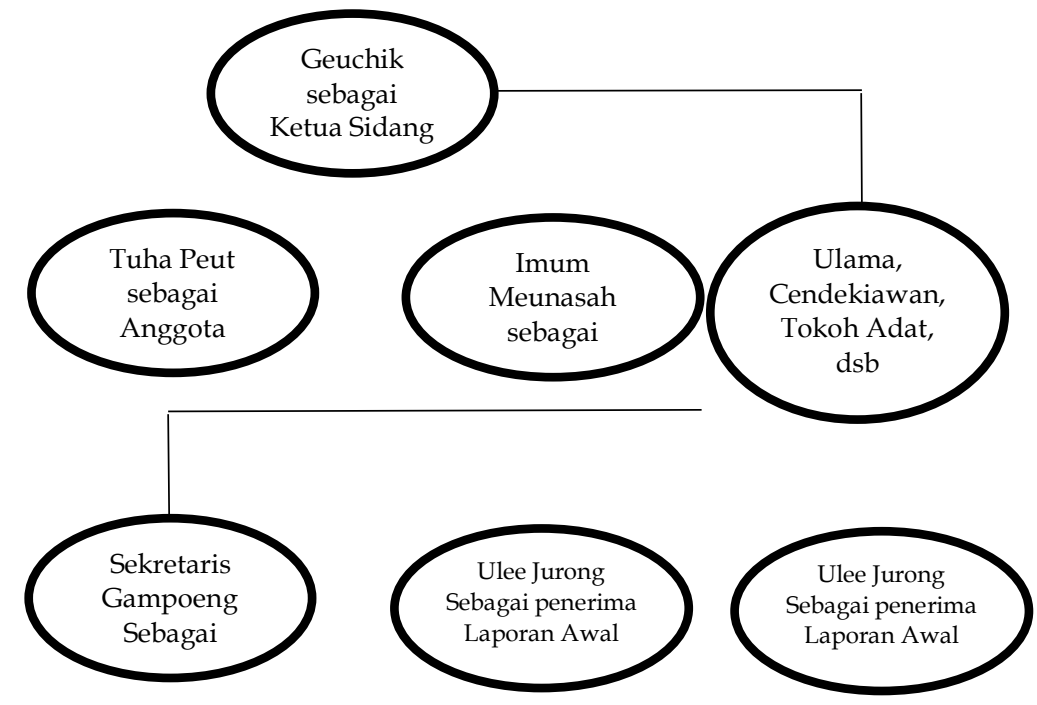

Skema di atas menggambarkan individu-individu yang tergabung dalam sistem peradilan gampoeng. Posisi Ketua Sidang tidak kaku sebagaimana tertera pada skema di atas. Boleh jadi geuchik menunjuk ketua lembaga adat sesuai jenis sengketa yang akan diselesaikan. Sebagai contoh jika konflik berkaitan batas sawah, maka geuchik berhak menunjuk keujruen blang sebagai ketua sidang. Sementara jika kasus yang disengketakan berkaitan dengan harta waris, bisa saja geuchik menunjuk imum meunasah sebagai ketua sidang. Fleksibeltas ini didasarkan pada wilayah kasus dan kompetensi para pemangku lembaga adat. ${ }^{58}$

Mencermati pada jabatan dalam peradilan gampoeng yang ada dalam masyarakat dengan model peradilan gampoeng yang sedang dalam proses sosialisi tidaklah jauh berbeda dengan peradilan gampoeng telah berproses selama ini. Perbedaan

\section{${ }^{56}$ Ibid.}

57Tim MAA Aceh dan UNDP, Pedoman Peradilan Adat di Aceh: Peradilan Adat yang Adil dan Akuntabel (Indonesia: Bappenas,Europen Union Aceh Peace Process Support UNDP, t.t.)

${ }^{58}$ Wawancara dengan Bapak Mansur Saidi, Pengurus MAA Kabupaten Bireuen Bidang Adat, Bireuen 15 November 2009. 
terletak pada posisi yang dijabat dalam peradilan, dimana dalam peradilan yang sedang dalam proses sosialisasi, sekretaris desa sebagai panitera, dan posisi tokoh adat lainnya sebagai anggota. Sementara dalam model peradilan gampoeng yang selama ini dipraktekkan dalam masyarakat tidak terungkap jabatan sekretaris desa di dalamnya. Akan tetapi model peradilan gampoeng sebagaimana yang digambarkan di atas belum berjalan, karena model ini masih dalam tahap sosialisasi. Sedangkan model peradilan gampoeng yang masih dipraktekkan dalam masyarakat masih sangat sederhana sebagaimana yang telah penulis uraikan di atas berdasarkan data hasil observasi.

Menyangkut dengan tempat penyelesaian sengketa waris menurut beberapa responden yang penulis wawancara, tidak dilaksanakan di meunasah atau di mesjid mengingat masalah ini menyangkut masalah keluarga, tidak ingin disaksikan oleh masyarakat banyak. Proses peradilan gampoeng pada kasus warisan biasanya dilakukan di rumah geuchik, imum meunasah atau di kantor desa dan tertutup untuk umum. Perbedaan tempat pelaksanaan peraadilan gampoeng terhadap kasus kewarisan dengan sengketa lain disebabkan oleh sifatnya rahasia, menyangkut aib pribadi dan keluarga. Sedangkan untuk sengketa selain sengketa waris biasanya diselesaikan di meunasah atau di mesjid dan terbuka untuk umum. ${ }^{59}$

Hasil observasi di Desa Bireuen Meunasah Blang Kacematan Kota Juang Bireuen, ditemukan kegiatan proses peradilan gampoeng yang dilaksanakan di rumah imum meunasah, dihadiri oleh imum meunasah, geuchik, sekretaris desa, kepala dusun, tokoh masyarakat, imum mukim dan para ahli waris atau para pihak.

Sidang dibuka oleh geuchik, setelah menyampikan puji-pujian, penghormatan dan ucapan terima kasih, dalam kata pembukaannya geuchik menekankan bahwa penyelesaian sengketa ini diselesaikan secara damai dan kekeluargaan. Oleh karena itu ia mengharapkan agar penyelesaian sengketa dapat dilakukan dengan sikap keterbukaan. Kemudian geuchik meminta tokoh masyarakat membacakan hasil sidang sebelumnya yang sudah pernah dilaksanakan pada tahap pertama.

Tahap selanjutnya tokoh masyarakat ${ }^{60}$ yang hadir memulai melakukan absensi kehadiran para ahli waris. Pada saat itu salah seorang ahli waris tidak hadir karena berdomisili di Jakarta. Namun ia memberikan kuasa kepada salah satu saudaranya yang laki-laki, dan saudara laki-laki menyerahkan surat kuasa kepada geuchik beserta foto copy Kartu Tanda Pengenal (KTP), yaitu foto copy KTP ahli waris yang memberikan kuasa kepadanya dan foto copy KTP penerima kuasa.

${ }^{59}$ Ibid.

${ }^{60}$ Kebetulan tokoh masyarakat tersebut adalah Imum mukim di kemukiman Bireuen, namun kehadiran beliau bukan dalam kapasitasnya sebagai imum mukim, tetapi sebagai tokoh masyarakat. 
Proses persidangan selanjutnya adalah pembagian harta pusaka yang diterima oleh masing-masing harta warisan sesuai dengan hak masing-masing ahli waris. Sebagai catatan bahwa pada sidang sebelumnya telah dilakukan perhitungan jumlah seluruh harta warisan baik dalam bentuk benda bergerak, benda tidak bergerak dan uang. Kesemua jenis harta telah dijelaskan bagian yang diterima oleh masing-masing ahli waris. Selama proses persidangan sempat terjadi ketegangan atau adu argumentasi antara dua orang ahli waris dari pihak yang berbeda. Saat itu juga geuchik menertibkan sidang, sehingga suasana persidangan kembali tertib.

Berdasarkan dari hasil observasi di atas menunjukkan bahwa sidang diketuai oleh geuchik, sekretaris desa sebagai sekretaris atau panitera. Sementara imum meunasah, kepala dusun dan tokoh masyarakat tidak jelas posisinya. Berdasarkan hasil wawancara dengan sejumlah responden ada yang mengatakan sebagai penasehat (penasehat di sini adalah yang memberikan nasehat ketika sidang sedang berjalan), ada juga yang mengatakan sebagai anggota atau saksi.

\section{Peradilan Mukim}

Di Aceh juga dikenal peradilan mukim mempunyai fungsi sama dengan peradilan gampoeng. Kedua bentuk peradilan ini merupakan peradilan adat. Hanya saja hirarki (tingkat) peradilanya saja yang menjadi perbedaan. Peradilan gampoeng adalah peradilan tingkat pertama, sedangkan peradilan mukim yaitu peradilan tingkat banding. Peradilan mukim berwenang menyelesaikan sengketa yang terjadi dalam masyarakat apabila proses penyelesaian melalui peradilan gampoeng tidak berhasil, maka kasus tersebut diajukan kepada peradilan mukim. Selain itu peradilan mukim juga menyelesaikan perkara tapal batas desa. Kasus ini tidak dapat diselesaikan di peradilan gampoeng, karena sengketa tersebut adalah sengketa antar desa, sehingga perkara antar desa tidak dapat diselesaikan melalui peradilan gampoeng.

Secara struktural, peradilan mukim terdiri dari imum mukim, yang bertindak sebagai pimpinan sidang adalah Imum Mukim Anggota terdiri dari Majelis Adat Mukim, imum Chik (Imam Mesjid Kemukiman), tuha peut mukim, dan ulama cendekiawan, tokoh adatlainnya. Sedangkan panitera adalah sekretaris mukim.

Sejauh data diperoleh tidak ditemukan adanya kasus kewarisan yang diselesaikan melalui peradilan mukim. Informasi dari beberapa responden mengatakan bahwa umumnya kasus kewarisan dapat diselesaikan di tingkat gampoeng. Akan tetapi terhadap kasus yang ada di desa Lapang Barat Kecamatan Gandapura terdapat sebuah kasus kewarisan yang tidak dapat diselesaikan melalui peradilan gampoeng, tetapi diajukan langsung ke Mahkamah Syar'iyah Bireuen melalui perantara 
pengacara. ${ }^{61}$ Pengajuan kasus ini menurut salah ahli waris lain disebabkan ahli waris tersebut tidak sabar menunggu proses penyelesaian sengketa di gampoeng. Menurut imum mukim Kecamatan Gandapura Timu bahwa tidak berjalannya peradilan mukim disebabkan belum ada qanun yang mengatur tentang tugas dan wewenang imum mukim. ${ }^{62}$ Padahal jika imum mukim menggunaka kaedah pemberlakuan suatu hukum sebelum adanya ketentuan hukum atau aturan baru, maka hukum yang digunakan adalah hukum atau ketentuan yang sedang berjalan, tanpa perlu menunggu ketentuan baru, sehingga eksistensi suatu lembaga tetap berjalan

Walapun demikian, imum mukim mengakui bahwa para kepala desa atau aparat desa lainnya tidak pernah menyampaikan atau mengajukan kepada pihak mukim tentang kasus perselisihan pendapat yang tidak dapat diselesaikan di tingkat gampoeng. ${ }^{63}$ Menurut Sekretaris Desa Bireuen Meunasah Blang mengatakan bahwa apabila upaya menyelesaikan sengketa waris di tingkat gampoeng tidak selesai, maka disarankan agar diselesaikan melalui Mahkamah Syar'iyah. ${ }^{64}$ Dari pernyataan tersebut menunjukkan bahwa aparat desa khususnya desa Bireuen Meunasah Blang tidak mengajukan kasus yang tidak dapat diselesaikan ditingkat desa diajukan ke tingkat mukim.

Menurut beberapa tokoh adat yang telah diwawancarai berpendapat keputusan peradilan gampoeng sifatnya sudah final. Para pihak yang tidak menerima keputusan dari peradilan gampoeng, biasanya mereka mengajukan perkearanya ke Mahkamah Syar'iyah. Di pihak Mahkamah Syar'iyah perkara tersebut justru dikembalikan kepada keputusan peradilan gampoeng. Jika salah satu pihak keberatan dan memiliki bukti baru yang kuat, Mahkamah Syar'iyah mempelajari dan mencari bukti-bukti serta memanggil aparat desa atau pihak-pihak yang terlibat dalam proses peradilan gampoeng. 65

Bagi hakim Mahkamah Syar'iyah Bireuen mengatakan bahwa apabila Mahkamah Syar'iyah mendapatkan pengajuan sengketa waris yang telah diputuskan dan telah ditandatangani oleh semua pihak, maka Mahkamah Syar'iyah tetap menerima kasus tersebut untuk dipreiksa kembali hasil damai yang diselesaikan oleh

${ }^{61}$ Wawancara dengan salah satu pihak yang bersengketa di Desa Lapang Barat Kecamatan Gandapura, 26 Oktober 2009.

${ }^{62}$ Wawancara dengan Drs. Yusuf Adami, Imum Mukim Gandapura Timu, Geureugok 1 Oktober 2009.

${ }^{63}$ Ibid.; Wawancara dengan Bapak Syarifuddin B, Imum Mukim Geulanggang Baro, Kecamatan Kota Juang, Cureh 30 Oktober 2009.

${ }^{64}$ Wawancara dengan Muhammad Yani, Sekretaris Desa Bireuen Meunasah Blang Kemukiman Bireuen Kecamatan Kota Juang, di Desa Bireuen Meunasah Blang 29 Oktober 2009.

65Wawancara dengan Tgk. Thahir Idris, Tokoh Masyarakat Desa Cot Pu'uk Kecamatan Gandapura, Cot Pu'uk, Tanggal 28 Oktober 2009; Wawancara dengan Bapak Mansur Saidi, Pengurus MAA Kabupaten Bireuen Bidang Adat, Bireuen 15 November 2009. 
peradilan gampoeng dan alasan penolakannya. ${ }^{66}$ Pemeriksaan kembali terhadap putusan dari peradilan gampoeng walaupun sudah ditandatangani oleh para pihak didasarkan pada keputusan peradilan gampoeng sifatnya tidak mengikat dan tidak bisa dieksekusi, karena prosesnya dilakukan melalui cara damai, bukan putusan hukum. Sedangkan hasil dari persidangan di peradilan adalah putusan hukum dan sifatnya mengikat serta bisa dieksekusi.

Walaupun keputusan hukum diputuskan berdasarkan keputusan peradilan gampoeng.67 Nampaknya pemutusan perkara oleh Mahkamah Syar'iyah yang didasarkan pada keputusan peradilan gampoeng bertujuan agar keputusan tersebut merupakan keputusan yang final dan mengikat serta dapat dieksekusi. Sementara terhadap keputusan dari peradilan gampoeng yang tidak ditangani oleh salah satu pihak, maka keputusan tersebut dianggap batal. 68

Berbeda halnya aturan yang terdapat dalam buku Pedoman Peradilan Adat Aceh dan juga Peraturan Daerah (Perda) Nomor 7 Tahun 2000 tentang Penyelenggaraan Kehidupan Adat pasal 14 ayat 1 mengatakan bahwa: "segala perselisihan dan persengketaan yang telah didamaikan oleh keuchik dan imum mukim dalam suatu rapat adat bersifat mengikat pihak-pihak yang berselisih/bersengketa" . Ayat 2 menyebutkan: "para pihak yang tidak mengindahkan keputusan adat tingkat keuchik dan imum mukim akan dikenakan sangksi adat yang lebih berat karena merusak kata kesepakatan dan mengganggu keseimbangan yang hidup dalam masyarakat". Berdasarkan ketentuan tersebut di atas jelas menyatakan bahwa putusan peradilan adat sifatnya mengikat, dan sudah final.

Penguatan peradilan adat jug tertuang dalama Rancangan Surat Keputusan Bersama (SKB) antara Gubernur, Kepala Polisi Daerah dan Ketua MAA tentang Penyelenggaraan Peradilan Adat di Gampoeng dan Mukim pada pasal 6 ayat 1 menyebutkan: Setiap putusan yang ditetapkan oleh Peradilan Adat Gampoeng dan Peradilan Adat Mukim karena diktum amar putusannya bersifat damai "putusan tetap" (persetujuan para pihak), maka putusan itu bersifat "putusan tetap". Dalam pasal yang sama ayat 3 menyebutkan: "Putusan damai sebagai keputusan tetap sebagaimana dimasksud pada ayat 1 di atas tidak dapat diajukan lagi tuntutannya pada lingkungan peradilan negara".

${ }^{66}$ Wawancara dengan Drs. Ahmad Yani, Hakim Mahkamah Syar'iyah Bireuen, Bireuen, Tanggal 16 Desember 2009.

67Wawancara dengan Drs. Bakhtiar, Panitera pada Mahkamah Syar'iyah Bireuen, Bireuen, Tanggal 16 Desember 2009.

${ }^{6} \mathrm{Ibid}$. 
Kalau SKB ini telah disahkan, maka kedepan keputusan dari peradilan adat baik tingkat gampoeng maupun tingkat mukim nampaknya tidak ada jalan lain untuk mencari penyelesaiannya. Mengingat SKB itu belum disahkan, maka SKB tersebut belum bisa diterapkan dalam sistum hukum di Aceh. Kalau merujuk kepada PERDA Nomor 7 Tahun 2000 sebagaimana yang tersebut di atas, maka kekuatan hukum dari proses peradilan gampoeng walaupun sifatnya bukan putusan hukum, namun memiliki kekuatan hukum yang kuat dan sudah dianggap final, dan pihak yang mangkir terhadap hasil perdamaian akan menerima sangksi adat, walaupun tidak bisa dieksekusi.

\section{G. Penutup}

Masyarakat Aceh di Kabupaten Bireuen telah menerapkan teori-teori modern dalam menyelesaikan sengketa warisan dengan berbagai variasi dan istilah yang terdapat dalam kearifan lokal. Teori negosiasi, konsultasi dan fasilitasi relatif banyak digunakan oleh masyarakat di Kabupaten Bireun untuk menyelesaikan sengketa warisan. Praktek aparatur desa dalam menyelesaikan sengketa melalui sistem peradilan adat; peradilan gampoeng dan peradilam mukim sejalan dengan prinsip umum yang terdapat dalam teori ADR, yaitu mengedepankan perdamaian, bukan kepastian hukum. Prinsip inilah menjadikan masyarakat Bireun cenderung memilih model penyelesaian sengketa warisan, dimana semua pihak atau komponen masyarakat Bireun dapat terwakili dalam proses persidangan. Di samping itu, pilihan masyarakat menyelesaikan sengketa melalui ADR lebih menjamin kerahasiaan persoalan keluarga, sehingga tidak diketahui oleh masyarakat umum.

Dampak yang dirasakan dari proses peradilan adat ini adalah terwujudnya perdamaian hakiki, tanpa menyisakan konflik antar sesama anggota keluarga. Bagi masyarakat Bireun ikatan kekeluargaan atau persaudaraan adalah hal utama yang harus dipelihara, walaupun terkadang mereka rela mengorbankan sebagian haknya untuk menjaga keutuhan hubungan kekeluargaan. Kecenderungan masyarakat Bireun memilih sistem peradilan adat (non litigasi) dalam sengketa warisan menunjukkan bahwa penyelesaian model ADR sejalan dengan prinsip adat yang berlaku secara turun temurun di masyarakat Aceh, sekaligus dapat bersanding dengan sistem peradilan negara, juga turut mengakui keputusan damai yang diperoleh melalui peradilan gampoeng atau peradilan mukim.

\section{DAFTAR PUSTAKA}

Abbas, Syahrizal. "Diyat dalam Kehidupan Sosial Budaya Masyarakat Aceh." Media Syariah VI, no. 11 (2004). 
- - - Mediasi Dalam Perspektif Hukum Syariah, Hukum Adat, dan Hukum Nasional. Banda Aceh: Raja Grafindo Persada, 2009.

Azwad, Ridwan. Aceh Bumi Iskandar Muda. Banda Aceh: Pemerintah Provinsi Nanggroe Aceh Darussalam., 2008.

Azwar, Muhammad. "Prospek Penerapan Online Dispute Resolution dalam Upaya Penyelesaian Sengketa Bisnis di Indonesia." Media Juris 2, no. 2 (2019): 179-196. https:/ / e-journal.unair.ac.id/MI/article/view/13912.

Djuned., T. "Penerapan Sistem dan Asas-asas Peradilan Hukum Adat dalam Penyelesaian Perkara." In Pedoman Adat Aceh: Peradilan dan Hukum Adat, diedit oleh M. Isa Sulaiman dan H. T. Syamsuddin. Banda Aceh: LAKA, 2001.

Galanter, Marc. “Justice in Many Rooms: Courts, Private Ordering and Indegenous Law." Journal of Legal Pluralism, no. 19 (1981).

Hasjmy, A. Kebudayaan Aceh dalam Sejarah. Jakarta: Beuna, 1983.

Hoesin., Moehammad. Adat Atjeh. Banda Aceh: Dinas Pendidikan dan Kebudayaan Propinsi Daerah Istimewa Aceh, 1970.

Hurgronje, Snouck. Aceh: Rakyat dan Adat Istiadatnya (I). Jakarta: INIS, 1996.

_ - _. Aceh Dimata Kolonialis. Jilid I. Jakarta: Yayasan Soko Guru, 1985.

Itam, Teuku Raja. "Penyelesaian Sengketa dan Bebagai Kasus." In Pedoman Adat Aceh: Peradilan dan Hukum Adat, diedit oleh M. Isa Sulaiman dan H. T. Syamsuddin. Banda Aceh: LAKA, 2001.

M. Zainuddin. Tarich Atjeh dan Nusantara. Medan: Pustaka Iskandar Muda, 1961.

Mamudji, Sri. "Mediasi Sebagai Alternatif Penyelesaian Sengketa Di Luar Pengadilan." Jurnal Hukum $\mathcal{E}$ Pembangunan 34, no. 3 (2017): 194-209. http://jhp.ui.ac.id/index.php/home/ article/view/1440/1360.

Manyambeang, Abdul Kadir. Keuchik dan Keujruen Blang dalam Masyarakat Aceh. Banda Aceh: Pusat Penelitian Ilmu-ilmu Sosial, 1979.

Margono, Suyud. ADR: Alternative Dispute Resolution dan Arbritase Proses Pelembagaan dan Aspek Hukum. Jakarta: Ghalia Indonesia, 2004.

Mujiburrahman dkk. Eksistensi dan Peran Lembaga Adat dalam Masyarakat di Propinsi Nanggroe Aceh Darussalam. Banda Aceh: Laporan Penelitian, Satuan Kerja BRRRrevitalisasi dan Pengembagan Kebudayaan NAD, 2006.

Rahmadi, Takdir. Mediasi Penyelesaian Sengketa Melalui Pendekatan Mufakat. Jakarta: Raja Grafindo Persada, 2011.

Rusdi Sufi dkk. Aceh Tanah Rencong. Yogyakarta: Multi Sosulindo Press, 2008.

Soemartono, Gatot. Arbitrase dan Mediasi di Indonesia. Jakarta: Gramedia Pustaka Utama, 2006. 
Sumardi, Dedy, Ratno Lukito, dan Moch Nur Ichwan. "Legal Pluralism within the Space of Sharia: Interlegality of Criminal Law Traditions in Aceh, Indonesia." Samarah 5, no. 1 (2021): 426-449. https://doi.org/10.22373/sjhk.v5i1.9303.

Tim Peneliti IAIN Ar-Raniry dan Biro Keistimewaan Aceh Provinsi NAD. Kelembagaan Adat Provinsi Nanggroe Aceh Darussalam. Banda Aceh: Ar-Raniry Press, 2006.

UNDP, Tim MAA Aceh dan. Pedoman Peradilan Adat di Aceh: Peradilan Adat yang Adil dan Akuntabel. Indonesia: Bappenas,Europen Union Aceh Peace Process Support UNDP, n.d.

Wijaya, Gunawan. Alternatif Penyelesaian Sengketa. Jakarta: Raja Grafindo Persada, 2005.

Yani, Gunawan Widjaya dan Ahmad. Hukum Arbitrase. Jakarta: Raja Grafindo Persada, 2003.

Peraturan Daerah Provinsi Aceh Nomor 7 Tahun 2000 tentang Penyelenggaraan Kehidupan Adat Pasal 1 ayat 11.

Wawancara Bapak Bakhtiar, Tokoh Masyarakat Desa Lingka Kuta, Kecamatan Gandapura, 27 Desember 2009.

Wawancara dengan A. Rahman Imum Mukim Buket Rata, Kecamatan Gandapura, Cot Teubee, 26 Oktober 2009.

Wawancara dengan Bapak Mansur Saidi, Pengurus MAA Kabupaten Bireuen Bidang Adat, Bireuen 15 November 2009.

Wawancara dengan Bapak Syarifuddin B, Imum Mukim Geulanggang Baro, Kecamatan Kota Juang, Cureh 30 Oktober 2009.

Wawancara dengan Bapak Umar Hasan, Ketua MAA Kabupaten Bireuen, 30 September 2009.

Wawancara dengan Drs. Ahmad Yani, Hakim Mahkamah Syar'iyah Bireuen, Bireuen, Tanggal 16 Desember 2009.

Wawancara dengan Drs. Bakhtiar, Panitera pada Mahkamah Syar'iyah Bireuen, Bireuen, Tanggal 16 Desember 2009.

Wawancara dengan Drs. Yusuf Adami, Imum Mukim Gandapura Timu, Geureugok 1 Oktober 2009.

Wawancara dengan Muhammad Yani, Sekretaris Desa Bireuen Meunasah Blang Kemukiman Bireuen Kecamatan Kota Juang, di Desa Bireuen Meunasah Blang 29 Oktober 2009.

Wawancara dengan Pak Amir, Keuchik Desa Cot Pu'uk, Jafar, Ketua Tuha Peut, Mursal Tuha Lapan Desa Cot Pu'uk Kecamatan Gandapura, Cot Pu'uk, 28 Oktober 2009.

Wawancara dengan salah satu pihak bersengketa di Desa Lingka Kuta, Lingka Kuta 27 Desember 2009. 
Wawancara dengan salah satu pihak yang bersengketa di Desa Bireuen Meunasah

Blang, Kecamatan Kota Juang, Bireuen Meunasah Blang, 8 Nopember 2009.

Wawancara dengan salah satu pihak yang bersengketa di Desa Lapang Barat Kecamatan Gandapura, 26 Oktober 2009.

Wawancara dengan Sofyan, warga masyarakat Desa Cot Teubee Kecamatan Gandapura, Cot Teubee 15 Oktober 2009.

Wawancara dengan Tgk. Murtadha Mustafa Kepala Desa Lingka Kuta, Lingka Kuta 27 Desember 2009.

Wawancara dengan Tgk. Thahir Idris, Tokoh Masyarakat Desa Cot Pu'uk Kecamatan Gandapura, Cot Pu'uk, Tanggal 28 Oktober 2009.

Wawancara dengan Tgk. Zakaria Imum Meunasah Desa Cot Pu'uk, Mursal Tuha Lapan Desa Cot Pu'uk. 